\title{
Evaluation of GIS based harvesting and marketing activities in beech $\log$ production areas (İnebolu forest sub-district sample)
}

\author{
Ender Buğday, ${ }^{1, *}$, Seda Erkan Buğday \\ 1,* Forest Engineering Dept. Faculty of Forestry, University of Çankırı Karatekin, 18100 Çankırl, Turkey. \\ ${ }^{2}$ Forest Engineering Dept. Faculty of Forestry, University of Kastamonu, 18100 Kastamonu, Turkey. \\ Corresponding author: enthere@gmail.com
}

\begin{abstract}
This study was focused on the planning of harvesting-production and marketing process in beech stands. İnebolu Forest Management District (FMD) has been selected as the study area. Potential beech timber forest with high economic values were identified, and estimated log production quantities were determined. In the marketing phase of the products obtained from harvesting, the best-optimum marketing place points for Forest Sub-district Directorates were determined with the help of geographic information systems. In this study, as the potential for beech timber areas of the İnebolu FMD, a total of 1482.2 hectares of land could be operated with timber production-harvesting oriented. According to the results, $82 \%$ of the pure and mixed beech forests could be directed to the stumpage and ramp sale and $18 \%$ to depot sales. In this respect, during the production-harvesting and after production, the periods of encountering abiotic and biotic pests of beech logs are reduced. So degradation and economical losses could be minimized.
\end{abstract}

Keywords: Forest harvesting, marketing, forest product, GIS.

\section{INTRODUCTION}

Humanity's demand for wood products based on wood continues to increase in a linear trend with time, and efforts are being made to meet this need in a controlled manner (Eraslan, 1974; Çoşkun, 1999; Daşdemir and Güngör, 2010). People's demands for products are satisfied realized through forest based activities. Thanks to the development of technology, the process of production and marketing of forest products has become quite fast (Acar ve Şentürk, 1996; Gül et al, 2000; Demir, 2002; Eker and Acar, 2006; Akay and Erdaş, 2007; Enez and Arıcak, 2012). The transportation and distribution process that is still unresolved in the marketing process, is an important handicap of forest products production and marketing (Akyüz et al, 2003; Acar and Eroğlu, 2001).

Although in Turkey; following more sensitive policies on forest assets (Güloğlu, 2010; Gümüş, 2014) and the distribution of forest products is quite costly, the demand for forest products has been increasing (Gültekin et al, 2009; Kayacan and Öztürk, 2009) and production is also increasing gradually. According to 2015 data; Turkey approximately 18 million $\mathrm{m}^{3}$ of annual allowable cut was decided to harvest from the forest assets by yearly (GDF, 2015). This annual allowable cut harvesting activities could be carried out more successfully by integrating production and marketing processes in a planned manner. As a matter of fact, the characteristics of the forest area is important for planning and decision process such as, vegetation (Flora, tree species, age, development age, stability, etc.), topographic structure (slope, altitude, slope length, concavity, convexity etc.), transport network (primary, secondary 
road density, quality of roads, the need for hydraulic structure etc.). Besides; in the harvesting operations in Turkey usually, forest villagers have been played an active role (Daşdemir and Kanburoğlu 2009, Özden and Erkan Buğday, 2015). The aforementioned features are some of the main features that should be taken into account when planning forestry production activities. Forest harvesting activities are generally carried out in forests spreading in steep terrains (Acar et al. 2002, Bayoğlu et al 1993, Acar and Şentürk 1993). Also, production-harvesting activities in forestry are shown as dangerous in Communiqué on Hazard Classes Regarding the Occupational Health and Safety (Anonymous, 2012).

When the production cycle is taken into consideration, forestry activities are faced with a multivariate equation such as the openness of the harvesting activities to be carried out to the natural events, the experience of various difficulties and necessities due to the land conditions, the availability of technology and the actual situation of the existing forest roads, standards and the adequacy of these roads. With so many variables, it is difficult for practitioners and / or decision-makers to make accurate decisions regarding the current production period or production in the following periods. This study is carried out in a sample area of production and marketing activities in the presence of beech forest. Beech, Turkey has a special place in the presence of forest and Turkey covers an area of forest assets $8.5 \%$ (GDF, 2012). Failure to plan reliable production in beech forest and wrong choice of sale and stacking place for beech log, causes the loss of value of beech log. In particular, the wood dote and trunk cracks on the beech products (Berkel et al 1968, Berkel et al 1978, Komut et al 2010) often cause undesirable change in the product and reduce the market value of the beech products. In this study, in order to minimize loss in value of products and to provide timely product to the market; production planning and right market location was tried to be determined. In this study; production and marketing activities carried out in beech stands have been evaluated and potential high economic value of beech stands has been determined. The conformity of the sites of production to stumpage sale, ramp and depot sales was evaluated by Geographic Information Systems (GIS) and thus, it was aimed to minimize the economic losses of beech logs by abiotic and biotic pests. In addition, production and marketing tactics in beech forests have been developed and it is aimed to minimize the economic damage caused by the waiting of beech.

\section{Material and Methods}

In this study, İnebolu Forest Management Directorate (FMD) was determined as the study area. 2017 production sections on the site were examined. During the study, the data of the Regional Directorate of Forestry of Kastamonu, data of ASTER GDEM and province demographic data, data obtained from the measurements made in the field were used as material.

\section{Study Area}

İnebolu FMD, which is located within the borders of Kastamonu Forest Regional Directorate (KOBM), consists of five Forest Sub-district Directorates, and designated as the study area (Fig.1). These subdistrict directorates names are respectively Altınkum, Doğanyurt, Gemiciler, İnebolu and Özlüce. The location of the forest sub-district directorates (FSD) within the boundaries of İnebolu FMD is given in Figure 1. According to the management plan of FSDs (Anonymous, 2011a,b,c,d,e) $70.9 \%$ of the general area of İnebolu FMD is forest and $85.5 \%$ of the forest assets is fertile. Beech is the most common tree species in the forest asset of İnebolu FMD. 


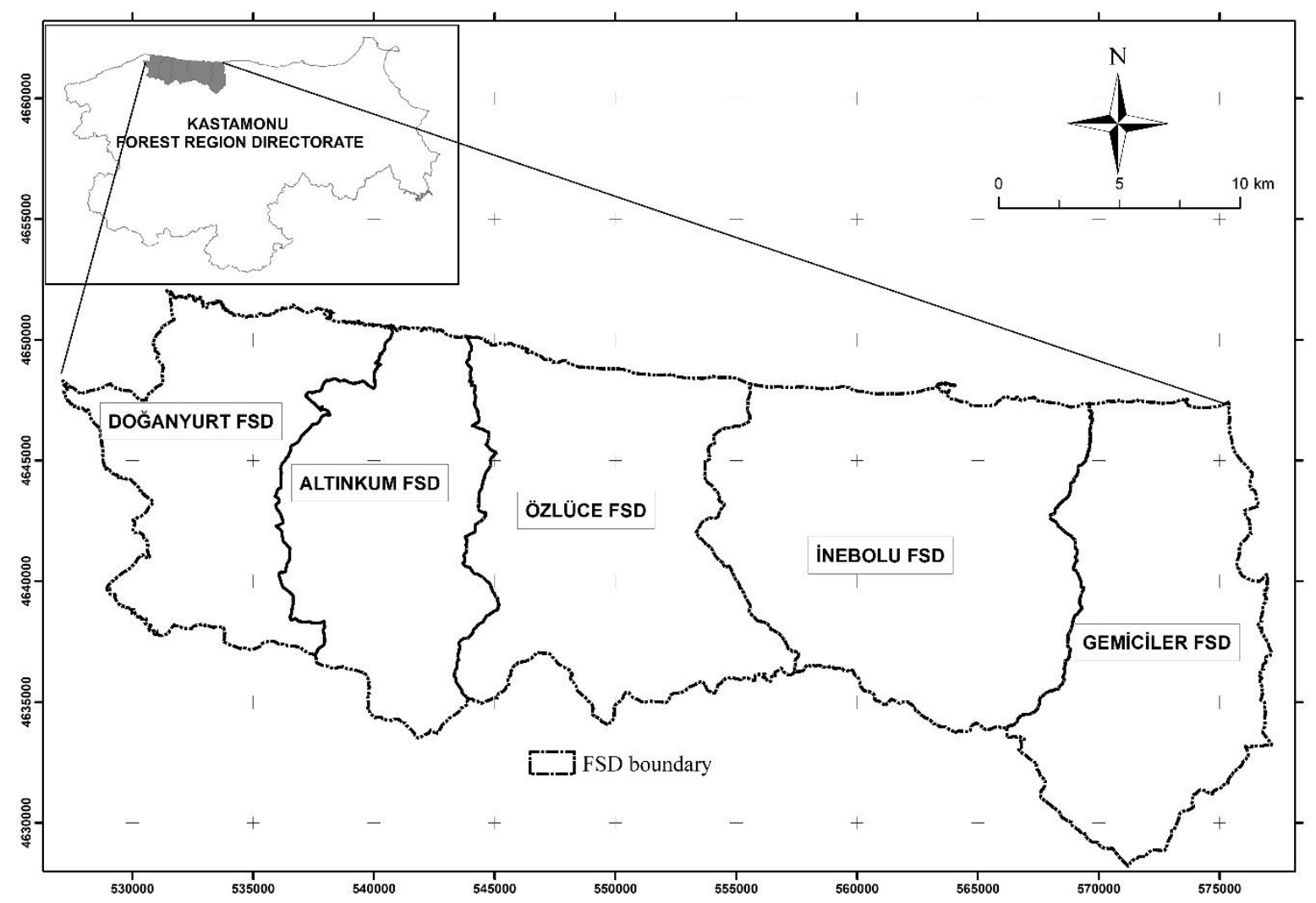

Fig. 1 The location of İnebolu Forestry Directorate and Sub-district Directorates

\section{METHOD}

This study was aimed to to evaluate GIS based production and marketing tactics in two stages as field and office work. During the field study, the ramps of the partitions, which were started to be produced in 2017, were determined. The coordinates of the ramp locations, which are actively used by the production workers, were taken and the general characteristics of the ramp locations were observed and recorded.

Firstly, the pure and mixture stands of beech; within the areas operated in the economic function were obtained from Table 2 in the Forest Management Plans (FMPs). The beech stands operated in the evenaged, uneven-aged and continuous form was determined in İnebolu Forests. In the economic function, the tree volumes per hectare to be silviculturally extracted from the even-aged enterprise classes were calculated using table 13 in İnebolu FMD FMPs.

The volume of trees to be harvested; only which is operated as uneven age; is taken from Table 31 and 31/a in İnebolu FMD FMPs. In the calculation of the estimated amount of product to be obtained from the volume of wood coming out of 1 hectare pure-mixed beech stands has been used of "Main Types of Products Carried by Our Tree Types" table. Formed by Osman SUN "Main Types of Products Carried by Our Tree Types" table has been used (Anonymous 2011a,b,c,d,e). This table is under the heading of "3.4.3.6. Product Types and Loss Rates to be Obtained from the Crustacean Volume and Arrangement". However, it should be reminded that "timber" of the products expressed in terms of the physical size of the products are of the standard size. Today's market and products separated as paperwork according to Turkish Standards Institution (TSE) standards are also included in SUN's timber classification. For beech wood species; II. $16.7 \%$ of the diameter class, III. $45.4 \%$ of the diameter class and IV. It is 
predicted that $70.2 \%$ of the diameter class can be produced as timber. Consequently; As a result of multiplication of the volume of trees to be taken from one hectare and the amount of beech logs that can be produced from each diameter class, the potential timber production amounts to be obtained from one hectare of each stand were determined. In this way, high economic value and potential beech fields have been identified. Also, the hierarchical cluster analysis was performed in SPSS 22 for clustering according to the amount of potential timber production in beech stands for each forest sub-districts.

In the process of preparation of digital terrain model, slope and survey maps of the study; Digital elevation model (DEM) data were processed using the ArcGIS 10.3 TM software. Dem data was downloaded from the section that is used free of charge at www.usgs.gov web site According to the limits of the study area. Elevation, slope and aspect maps were obtained by using Spatial Analyst module in ArcGIS 10.3 TM software.

In the study, the detection of stumpage, ramp and depot locations in GIS environment; The data on the road, forest road and forest road information of İnebolu Forest District (IFD) were analyzed. stumpage sales and ramp sales locations are determined by moving from road and village roads, which are standard roads where large and long vehicles can easily maneuver and travel safely. The areas suitable for depot sales are determined from the areas where forest roads are lower than those of road and village roads. In this study, the buffer zone was placed on both sides of the road and village roads to be $1000 \mathrm{~m}$. Due to the fact that the stands are close to the road in terms of production and suitable for the use of large and long vehicles, the remaining beech fields are determined as suitable places for stumpage and ramp sales and the remaining beech fields are determined as suitable areas for depot sales.

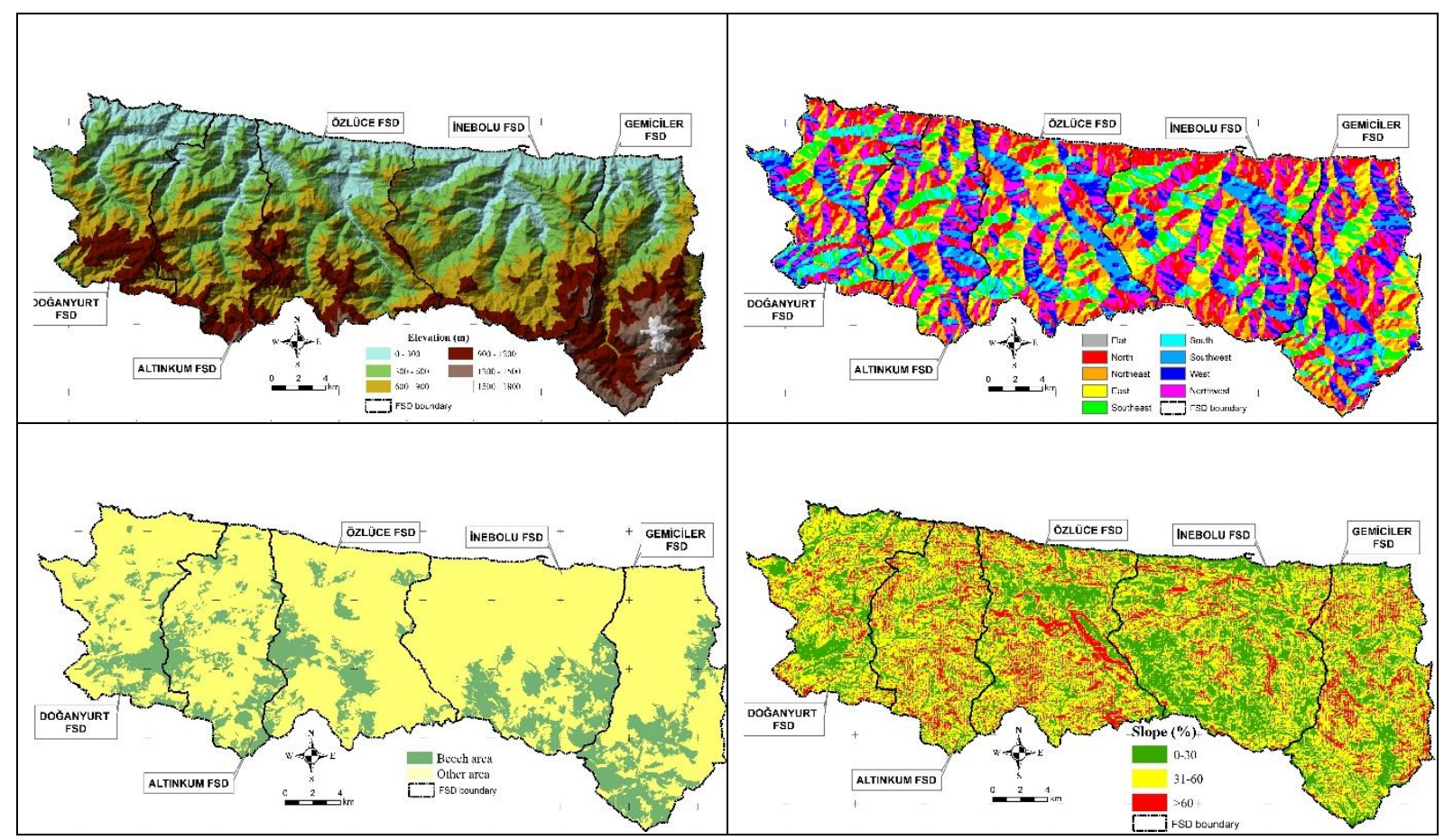

Fig. 2 Elevation, slope, aspect analysis and beech distribution map of the İnebolu FMD 


\section{RESULTS}

This study was carried out in four sub-headings. Primarily, the general characteristics of the study area and potential beech logs production areas were determined. Then marketing places of pure and mixed beech stands in economic function were analyzed. And also the preferred ramps for beech stands (in 2017) with predicted ramps were compared.

\section{Determination of the general characteristics of the study area}

In order to determine the topographical characteristics of the production; elevation, slope and aspect analysis of the İnebolu FMD were performed and the results were given beech distribution areas map (Figure 2). The average slope of İnebolu FMD was found to be $35 \%$. Within the İnebolu FMD borders are $32 \%$ of the general area are $0-30 \%$ slope class, $55 \%$ are in the slope class of $31-60 \%$ and $13 \%$ are in the $>60 \%$ slope class. The mean aspect of the İnebolu FMD is north. Doğanyurt FSD, İnebolu FSD's and Özlüce FSD's mean aspect was found to be the north. Gemiciler FSD's and Altıkum FSD's mean aspect are western north. The average height of the area within the boundaries of İnebolu FMD was calculated as 692 meters.

Approximately $44 \%$ of the forest areas within the boundaries of İnebolu FMD take place in the economic function. Pure and mixed beech stands operated in economic function; In Altınkum FSD, 6 $\%$ uneven-aged, $94 \%$ were the even-aged; In Doğanyurt FSD $9 \%$ were uneven-aged and $91 \%$ were even-aged; Gemiciler FSD $22 \%$ of uneven-aged and $78 \%$ even-aged; İnebolu FSD $16 \%$ of the unevenaged and $84 \%$ were even-aged; in Özlüce FSD, $5 \%$ of uneven-aged and $95 \%$ even-aged are operated.

\section{Determination of potential beech logs production areas}

In this study, potential timber production quantities of the even-aged and uneven-aged operated beech stands were calculated. However, due to the high amount of data in the data obtained, it was ensured that the stands were divided into clusters and grouped into groups with heterogeneous clusters. The results of the cluster analysis of the potential beech areas of each FSD were given in the figures and tables below (Figure 3-4). In this study; The areas with the lowest potential timber production quantities of beech stands are expressed as 1 and the highest areas are 5 .

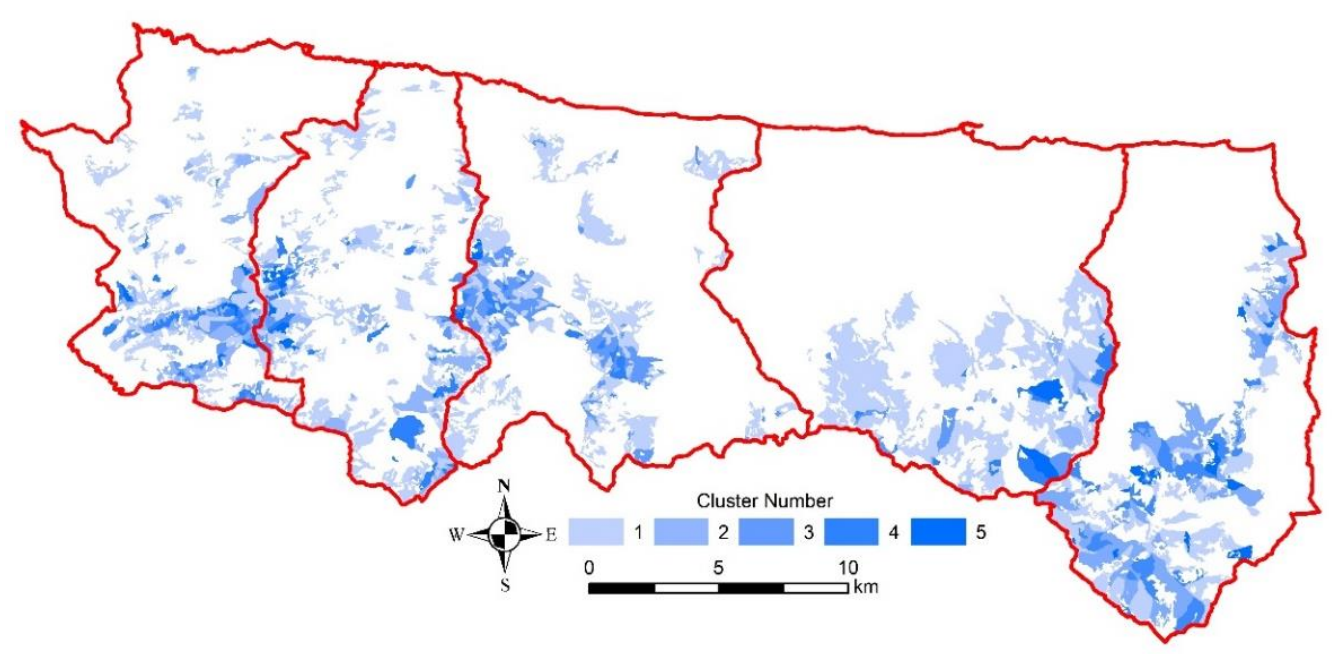

Fig. 3 The results of clustering analysis according to potential timber production quantities of beech stands 


\begin{tabular}{|c|c|c|c|c|c|c|}
\hline \multirow{8}{*}{$\stackrel{\pi}{\simeq}$} & \multirow{2}{*}{$\begin{array}{l}3000 \\
2500\end{array}$} & & & & & \\
\hline & & & & & & \\
\hline & \multicolumn{6}{|l|}{2000} \\
\hline & \multicolumn{6}{|l|}{1500} \\
\hline & \multicolumn{6}{|l|}{1000} \\
\hline & \multicolumn{6}{|l|}{500} \\
\hline & \multirow[t]{2}{*}{0} & $=\square$ & D & $1-$ & \multicolumn{2}{|c|}{ an } \\
\hline & & Altınkum & Doğanyurt & Gemiciler & Inebolu & Özlüce \\
\hline & 1. group & 1748,1 & 1046,6 & 1481,7 & 2816,2 & 2015,6 \\
\hline & 2. group & 471,9 & 570,4 & 1176 & 180,9 & 49,3 \\
\hline & 3. group & 142,3 & 161,4 & 629,3 & 198,2 & 684,6 \\
\hline & 4. group & 334,9 & 206,8 & 79,2 & 237,1 & 128,2 \\
\hline & 5. group & 87,9 & 55,8 & 178 & 137,1 & 37,6 \\
\hline
\end{tabular}

Fig. 4 Areas of groups according to cluster analysis

According to clustering analysis results, , the beech timber production was estimated as to intense in the 422.8 ha section in the 4th and 5th clusters for Altınkum FSD. Respectively, was calculated as 262.6 ha in Doğanyurt FSD, was calculated as 257.2 ha in Gemiciler FSD, was calculated as 374.2 ha in İnebolu FSD, was calculated as165.8 ha in Özlüce FSD.

\section{Determination of marketing places of pure and mixed beech stands in economic function}

Many factors-constraints has been thought to be effected in the determination of the market place in the beech stands in İnebolu FMD. The impact of the transport network on the detection of the marketplace has been examined in this study.

There are three types of roads in IFD boundaries: highway, village road and forest road. In fact, considering that all roads are used in secondary transport, and they affect the size of the transportation vehicles used in the transport of forest products; in the marketing process, the stumpage and ramps sales will be more successful in the beech stands surround the village roads and highways.

In today's conditions, in the stumpage and ramps sales process; The customers want to enter their big vehicles; suitable for intercity freight transportation; into the forest. For this reason, in this study $1 \mathrm{~km}$ buffer zone is placed on the right and left sides of the roads and village roads within the boundaries of İnebolu FMD. The suitability of the beech stands (in economic function) for stumpage-ramp and depot sales were determined.

The production activities to be performed at the level of FSD were given in Table 1 and the spatial distribution according to marketing place were presented in Figure 5.

A total of 12210.4 hectares of pure and mixed beech production in the İnebolu FMD borders can be sold to the market with the sale of stumpage or ramp sales. Because of the lack of adequate and high quality road, products harvested from 2845.8 hectares of forest area can be marketed from depot.

The most suitable market place for $92.2 \%$ of pure and mixed beech stands in Altınkum FSD is stumpage - ramp. Respectively, 93.8 \% of Doğanyurt FSD, 73.9 \% of Gemiciler FSD, 93.4\% of İnebolu FSD, 55.1 
$\%$ of Özlüce FSD are determined as suitable for stumpage and ramp sales in terms of secondary transport network.

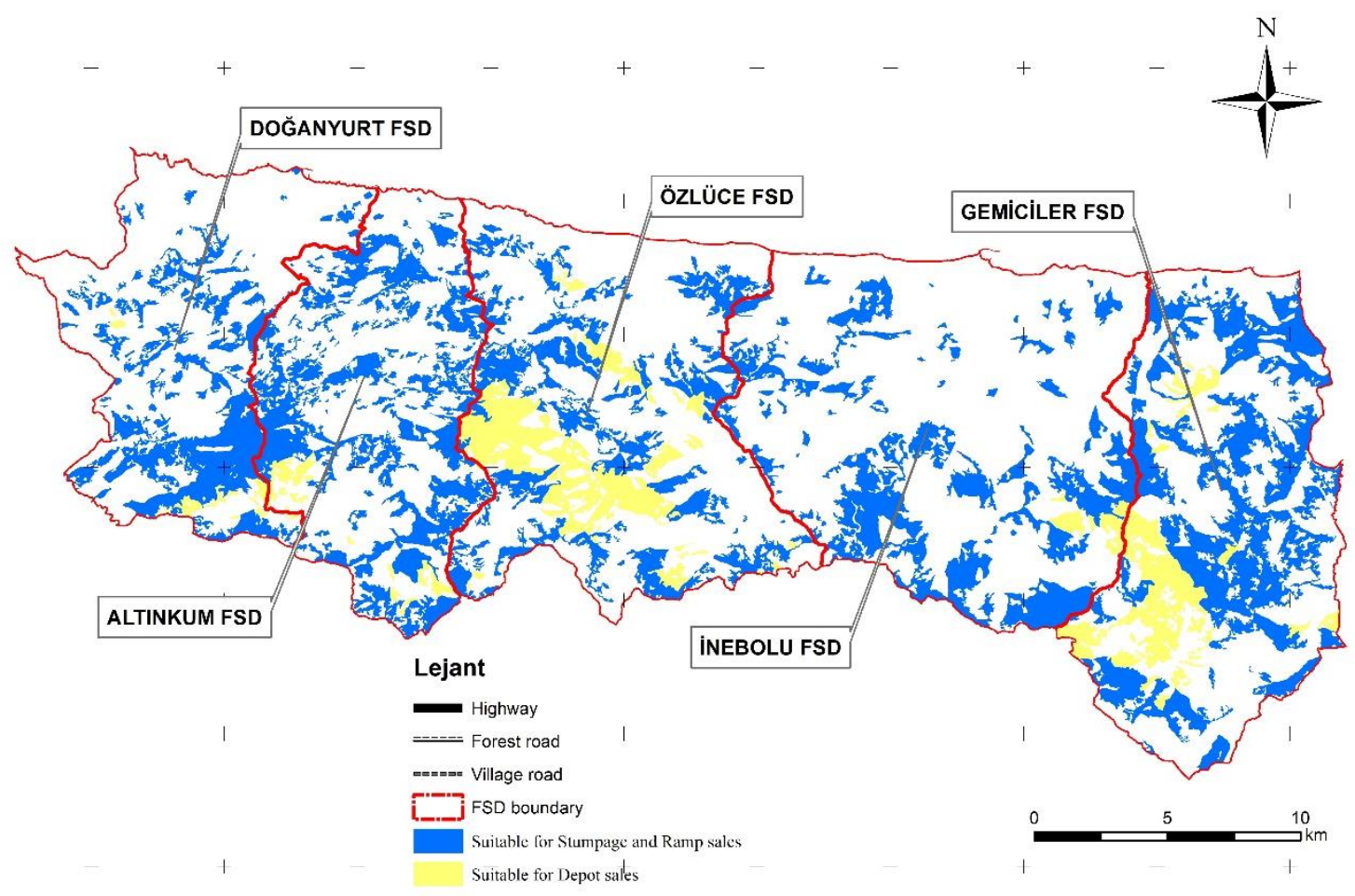

Fig. 5 The suitability of the beech stands (in economic function) for stumpage-ramp and depot sales

Table 1. Values of stumpage, ramp and depot areas

\begin{tabular}{lll}
\hline \multirow{2}{*}{ FSD } & \multicolumn{2}{c}{ Area (ha) } \\
& Stumpage-Ramp & Depot \\
\hline Altınkum & 2622.7 & 221.7 \\
Doğanyurt & 1924.4 & 127 \\
Gemiciler & 2675.3 & 943.8 \\
İnebolu & 3370.2 & 236.7 \\
Özlüce & 1617.8 & 1316.6 \\
Toplam & 12210.4 & 2845.8 \\
\hline
\end{tabular}

\section{Comparing the preferred ramps for beech stands (in 2017) with predicted ramps}

In 2017 years, 59 compartment (Nine ramps at Doğanyurt FSD, Altınkum FSD, İnebolu FSD and Gemiciler FSD, Özlüce FSD) were observed ongoing harvesting activities.

In 2017, optimal ramp areas were determined with the help of GIS of 59 compartments, which were determined as a sample area and given to production. In this study, it is aimed to determine the best and the most suitable ramp for the production and marketing of forest products. For this purpose, taking into account the average inclination of the sections where the ramp locations are sampled, the distance to the center of the polygon with the shortest distances to the road is calculated using the Euclidean distance method. 


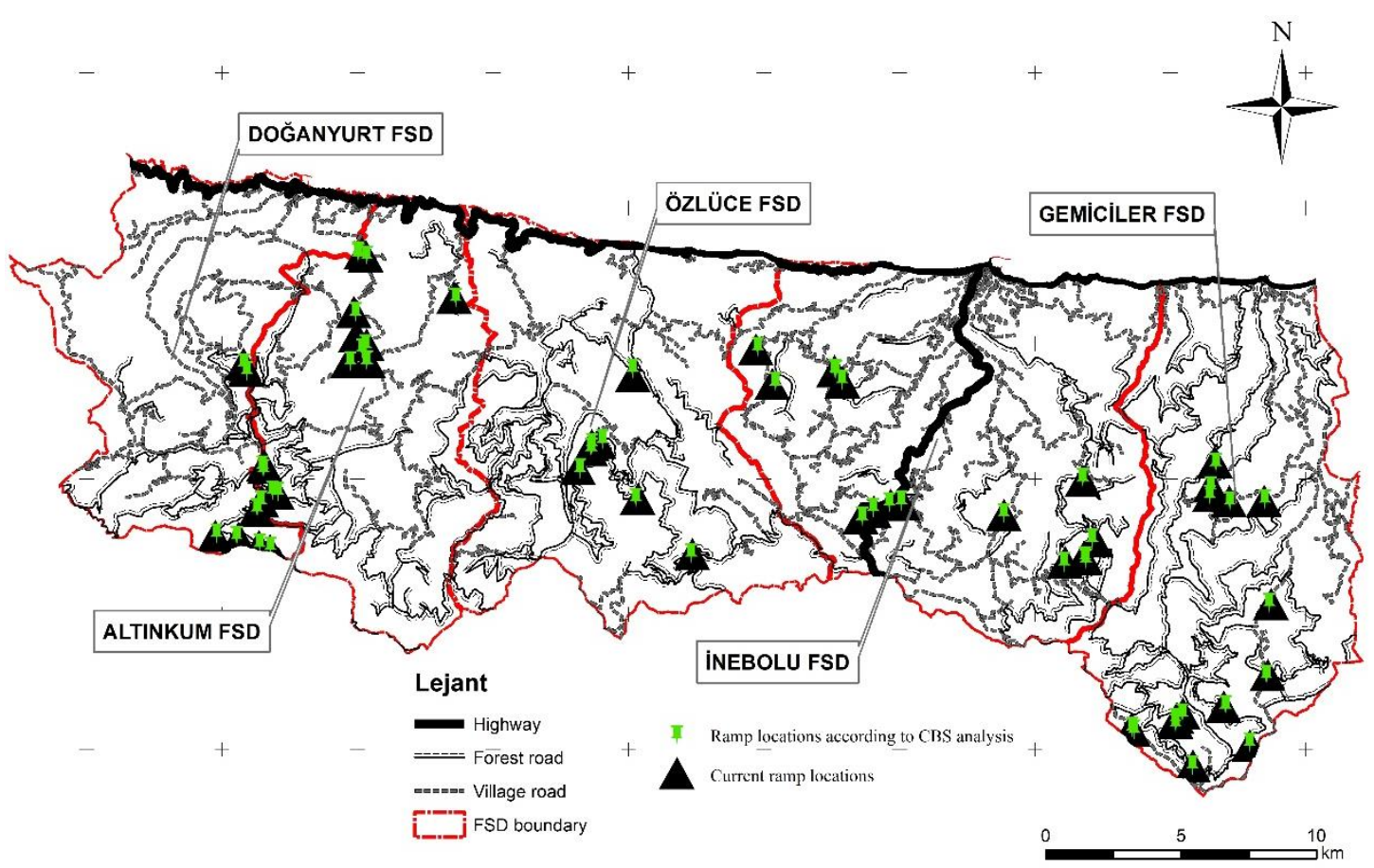

Figure 6. Optimal ramp locations for production sites

The optimal ramp locations were given Figure 6. When we examine the differences between the existing and optimal ramp areas within each chamber in a digital environment, it is seen that there is a difference between $11 \mathrm{~m}$ and $274 \mathrm{~m}$. In general, no significant differences were observed between the optimal ramp locations to be created when a homogeneous production was initiated in the whole compartment.

15 ramp locations were used between the areas as ramp locations of the products produced by the production workers and the ramp locations determined by GIS are similar areas were determined. In other words, one of every 4 ramps were observed during field work can be expressed as the most appropriate ramp area. Approximately $50 \%$ of the observed ramp areas were determined to have a difference of 50-100 meters between existing ramp areas and areas determined by GIS. Also, it was found that there was a difference of 100-274 meters between the ramp areas calculated with the help of GIS in one of every four ramps.

\section{Discussion and Conclusion}

Competitiveness in the world forest products market can be achieved through cheap raw materials, labor and quality products. It is therefore very important to focus on the production of forest products. The methods developed in the production of forest products also affect the marketing conditions and the product mix. In this study, due to the difficulty of land conditions on the 59 ramps observed, mostly, short material production carried out from the stands, and using the animal or a rope shot for primer transport were observed. In this study, in İnebolu, short length cutting of the products can be considered as a backward movement in the quality and standards of the goods to be offered to the market.

In general, it is observed that beech stands rise from the shore to the elevation of 1200 meters in İnebolu. The short production time at high altitudes and the difficulty of transportation conditions negatively affect the production and marketing. However, as a result of the analysis, high-yielding beech forests 
are generally attracted to high elevations and production and marketing are important especially in determining ramp locations. Production should be professionally both managed and carried out, at 422.8 ha in Altınkum FSD, 262.2 ha in Doğanyurt FSD, 257.2 ha in Gemiciler FSD, 374.2 ha in İnebolu FSD and 165.8 ha, in Beech Stands. Because this stands could be stated potential timber areas according to this study.

The amount of annual allowable cut per hectare in Özlüce FSD more than the other FSD was seen. While examining the ramps of Özlüce FSD, a valley and even the canyon, which passing through Özlüce FSD was remarkable in terms of harvesting-marketing. In Özlüce FSD, where the land conditions are quite harsh, it is thought that the production could not be realized due to the land conditions in the previous plan period. In this plan period, during harvesting activities process should be benefited from technology in particular. Gemiciler FSD is the highest elevation in İnebolu. Uneven aged forests are concentrated in the south and highest area of Gemiciler FSD. It is expected that a high amount of beech logs will be produced from these forests. And also, the stands in the age of "d" in the even-aged forest and $\mathrm{C}$ and $\mathrm{D}$ pinned stands in uneven-aged forest operated in economic function have more annual allowable cut, than common usual and conventional in İnebolu. In these stands, wealth accumulation is observed due to both the legislation and planning principles of the previous plan period. However, the annual allowable cut should be taken at least two different times during this plan period is important in terms of preserving the stability of the forest and not increasing its sensitivity to biotic and abiotic pests.

In the production of forest products, the amount of potential product that may emerge from the tree stigmatized in the classical forestry understanding is not determined in advance. Due to the production process taken a long time, it needs to be planned in advance, to reduce risks. Today in Turkey is increasing demand for imported forest products (Kurt et al 2011, Erkan Buğday 2016). Therefore, in order not to lose market share; potential product forest need to be determined in order to pre-planned the products to be placed on the market. In this study, the rates developed by Osman SAN, which is the key to the amount of product that can be produced by the forest management chief in the non-local but in the management plans, are used in the determination of the potential beech logs. The aim of this study was to determine the beech stands in Inebolu. However, in the product calculation, the products of both timber and pulpwood were calculated in the products which are considered as "timber". In these tables, which are given in the management plan, the amount that can be trashed in terms of physical measurements is revealed.

Another important issue in the production and marketing of beech is marketing-sales place. Due to the relatively low tolerances of beech logs at the sales place; it is very important to predetermine stumpage sale, ramp and depot sales. As a result of the study, according to Özlüce FSD, it was seen that the other FSD's were more suitable road network for ramp and stumpage sales. Therefore, a forest area like Özlüce FSD should be revaluated separately when planning.

In this study, the importance of production and marketing in forest management has been focused on. The studies of production planning carried out in Turkey; such as Eker and Acer (2006), Buğday (2015), etc.; should be increased. Also these studies should be tried on plot areas and the most appropriate methods or combinations of methods should be determined. Marketing-place strategies, which will be implemented together with production-harvesting planning, will contribute to offering quality products to both national and international forest products market. In subsequent studies, studies on production and marketing activities of tree species with different sensitivities can be made. 


\section{Acknowledgements}

This study, which was carried out within the scope of BAP-OF200217B18 project, was supported by Çankırı Karatekin University Scientific Research Projects Coordination Office. References

Acar, H. H., Eroğlu, H. 2001. Orman Yolları Üzerinde Odun Hammaddesi Nakliyatının Planlanması. Artvin Çoruh Üniversitesi Orman Fakültesi Dergisi, 2(1), 61-66.

Acar, H. H., Şentürk, N. 1993. Dağlık Arazide Orman Yollarının Planlanması ve Yapımı İle Üretim Çalışmalarının Orman Ekosistemi Üzerine Olan Etkileri. İstanbul Üniversitesi Orman Fakültesi Dergisi, 43(12), 103110.

Acar, H., Şentürk, N. 1996. Dağlık Orman Alanlarındaki Üretim Çalışmalarında Mekanizasyon. İstanbul Üniversitesi Orman Fakültesi Dergisi, 46(1-2-3-4), 77-94.

Acar, H., Şentürk, N., Topalak, Ö., Öztürk, T. 2002. İkizdere Yöresinde Koller K300 Orman Hava Hattının Verim Açısından İncelenmesi. İstanbul Üniversitesi Orman Fakültesi Dergisi, 52(2), 2738.

Akay, A. E., Erdaş, O. 2007. Orman Ürünlerinin Nakliyatının Planlanmasında Ă̆ (Network) Modeli Yaklaşımı. İstanbul Üniversitesi Orman Fakültesi Dergisi, 57(2), 1-20.

Akyüz, K. C., Serin, H., Akyüz, İ., Cındık, H. 2003. Doğu Karadeniz Bölgesindeki Orman Ürünleri Sanayi İşletmelerinin Hammadde Tercihleri ve Tedarik Sorunları. Kafkas Üniversitesi, Artvin Orman Fakültesi Dergisi, (1-2), 68-75.

Anonymous, 2011a. Kastamonu Orman Bölge Müdürlüğü İnebolu Orman İşletme Müdürlüğü Altınkum Orman İşletme Şefliği Fonksiyonel Orman Amenajman Planı s:353.

Anonymous 2011b. Kastamonu Orman Bölge Müdürlüğü İnebolu Orman İşletme Müdürlüğü Doğanyurt Orman İşletme Şefliği Fonksiyonel Orman Amenajman Planı s:333.

Anonymous 2011c. Kastamonu Orman Bölge Müdürlüğü İnebolu Orman İşletme Müdürlüğü Gemiciler Orman İşletme Şefliği Fonksiyonel Orman Amenajman Planı s:423.

Anonymous 2011d. Kastamonu Orman Bölge Müdürlüğü İnebolu Orman İşletme Müdürlüğü İnebolu Orman İşletme Şefliği Fonksiyonel Orman Amenajman Planı s:419.

Anonymous 2011e. Kastamonu Orman Bölge Müdürlüğü İnebolu Orman İşletme Müdürlüğü Özlüce Orman İşletme Şefliği Fonksiyonel Orman Amenajman Planı s:429.

Anonymous 2012. İş Sağlığı ve Güvenliğine İlişkin İşyeri Tehlike Sınıfları Tebliği Resmi Gazete Tarihi: 26.12.2012 Resmi Gazete Say1s1: 28509

Bayoğlu, S., Acar, H. H., Şentürk, N. 1993. Dağlık Arazide Bölmeden Çıkarma Araçlarında Maliyet Analizi ve Minimum Çalışma Süresinin Araştırılması. İstanbul Üniversitesi Orman Fakültesi Dergisi, 43(12), 4556.

Berkel, A., Bozkurt, Y., Göker, Y. 1968. Kayın Tomruklarında Ardaklanma ve Çatlamanın Önlenmesine Ait Bir Deneme. İstanbul Üniversitesi Orman Fakültesi.

Berkel, A., Bozkurt, Y., Göker, Y. 1978. Kayında Ardaklanma, Meşede Kahverengi Şeritlilik İle Her İki Ağac Cinsinde Çatlamanın Önlenmesi Üzerine Bir Deneme. İstanbul Üniversitesi Orman Fakültesi Dergisi A(28) 1.

Buğday, E. 2015. Sertifikalı Orman İşletmelerinde Odun Hammaddesi Üretim Planlarının Oluşturulması (Daday Orman İşletme Müdürlüğü Örneği). Çankırı Karatekin Üniversitesi, Fen Bilimleri Enstitüsü, Doktora Tezi, Çankırı.

Çoşkun, A. A. 1999. Türkiye'de Ormanlardan Yararlanmanın Yasal Esasları. İstanbul Üniversitesi Orman Fakültesi Dergisi, 49(1), 83-110.

Daşdemir, İ., Kanburoğlu, S. 2009. Devlet Orman İşletmelerinde Odun Hammaddesi Üretiminde Tahtacıların Rolü II. Ormancılıkta Sosyo-Ekonomik Sorunlar Kongresi 19-21 Şubat, Süleyman Demirel Üniversitesi, Isparta. 
Daşdemir, İ., Güngör, E. 2010. Çok Kriterli ve Katılımcı Yaklaşımla Orman Kaynaklarının İşlevsel Önceliklerinin Belirlenmesi: Ulus Devlet Orman İşletmesi Örneği. Bartın Orman Fakültesi Dergisi, 11.

Demir, M. (2002). Bolu Mıntıkasında Orman Yol Şebeke ve Nakliyat Planlarının Bilgisayar Ortamında Düzenlenmesi. İstanbul Üniversitesi Orman Fakültesi Dergisi, 52(2), 125-158.

Eker, M., Acar, H. H. 2006. Ormancılıkta Odun Hammaddesi Üretiminde Yıllık Operasyonel Planlama Modelinin Geliştirilmesi. Süleyman Demirel Üniversitesi Fen Bilimleri Enstitüsü Dergisi, 10(2).

Enez, K., Arıcak, B. 2012. Ağaç Hasat Makinesine Ait Teknik ve Çalışma Koşullarının Değerlendirilmesi. Journal of Science and Engineering, Kahramanmaraş Sütçü İmam Üniversitesi, 108-114.

Eraslan, İ. 1974. Türkiye'deki Orman Topraklarından Çok Amaçlı (Çok Yönlü) Faydalanmanın Planlanması Esasları. İstanbul Üniversitesi Orman Fakültesi Dergisi, 30-49.

Erkan Buğday, S. 2016. Oduna Dayalı Orman Ürünlerinde Stratejik Pazarlama Analizi (Kastamonu Orman Bölge Müdürlüğü Örneği). Çankırı Karatekin Üniversitesi Fen Bilimleri Enstitüsü Doktora Tezi.

GDF, 2012. Türkiye Ormanları. Orman Genel Müdürlüğü, Dış İlişkiler, Eğitim ve Araştırma Dairesi Başkanlığı, Ankara, ISBN:9786053930440.

GDF, 2015. Türkiye Orman Varlığı. Orman ve Su İşleri Bakanlığı Orman Genel Müdürlüğü, Ankara.

Gül, A. U., Acar, H. H., Topalak, Ö. 2000. Ormancılıkta Üretim Çalışmalarında Mekanizasyon İhtiyacının Doğrusal Programlama Yoluyla Belirlenmesi. TUBİTAK Doğa Dergisi, 23, 375-382.

Güloğlu, Y. 2010. Orman Mülkiyetinin Doğuşu ve Osmanlı Devletinde Tanzimat Dönemine Kadar Ormanlarla İlgili Yapılan Yasal Düzenlemeler. Kastamonu Üniversitesi Orman Fakültesi Dergisi, 10(2), 180-194.

Gültekin, Y. S., Kayacan, B., Ok, K. 2009. Düzce İli Orman Endüstrisinin Odun Hammaddesi Talebi Üzerine Araştırmalar. Düzce Üniversitesi Ormancılık Dergisi, 5(2), 75-94.

Gümüş, C. 2014. Osmanlıdan Günümüze Ormancılık Politikalarının Ormancılık Örgütlenmesi Üzerine Etkileri ve Güncel Sorunlar, II. Ulusal Akdeniz Orman ve Çevre Sempozyumu, 22-24.

Kayacan, B., Öztürk, A., 2009. Dünyada Orman Ürünleri Piyasa Modelleri: Gelişim Süreci ve Türkiye İçin Yönelimler, II. Ormancılıkta Sosyo-Ekonomik Sorunlar Kongresi, 19-21 Şubat 2009, Isparta.

Komut, O., İmamoğlu, S., Öztürk, A. 2010. Orman İşletmeleri Satış Depolarında Etkili Olan Zararlar Ve Alınabilecek Önlemler. III. Ulusal Karadeniz Ormancılık Kongresi. Cilt: I Sayfa: 270278.

Kurt, R., Çabuk, Y., Karayılmazlar, S. 2011. Türkiye ve Dünya Yuvarlak Odun ve Odun Dışı Orman Ürünlerinin Üretim, Dışı Ticaret Ve Ekonomik Potansiyel Analizi. Bartın Orman Fakültesi Dergisi, 13(20), 1-9.

Özden, S., Erkan Buğday, S. 2015. Üretim Faktörü Olarak Orman Köylüsünün Nüfus Hareketleri: Kastamonu Örneği. Kastamonu University Journal of Forestry Faculty, 15(2).

Submitted: 29.12.2018 Accepted: 30.01.2019 